\title{
Students' perceptions of the learning environment in two Nigerian medical schools offering different curricula
}

\author{
Olufunmilola A. Ogun ${ }^{1}$, Timothy E. Nottidge ${ }^{2}$ and Sue Roff ${ }^{3}$ \\ Ghana Med J 2018; 52(3): 116-121 doi: http://dx.doi.org/10.4314/gmj.v52i3.2 \\ ${ }^{1}$ Department of Ophthalmology, College of Medicine, University of Ibadan, Ibadan, Nigeria \\ ${ }^{2}$ Department of Orthopaedics and Traumatology, College of Health Sciences, University of Uyo, P.O. Box 1316, \\ Uyo, Nigeria \\ ${ }^{3}$ Centre for Medical Education, University of Dundee, Dundee, Scotland, United Kingdom
}

\author{
Corresponding author: Dr Timothy E. Nottidge \\ Conflict of interest: None declared
}

E-mail: timnottidge@yahoo.com

\section{SUMMARY}

Objective: Compare the results of administering the DREEM questionnaire in two Nigerian medical schools offering traditional and student-centred curricular respectively, to identify any differences in the learning environment and appreciate advantages of the more modern curriculum.

Methods: A survey design was used. Data was analysed using the DREEM scoring rubric. The independent t-test was used to compare results.

Setting: The DREEM questionnaire was administered to final year medical students at two participating centres.

Participants: Final year students of a teacher-centred and a student-centred medical school.

Results: There were 138 respondents - 50 (96.2\% of the final year students) from the teacher centred school and 88 (59.1\% of the final year students) from the student-centred school. The mean total DREEM score was 117+22.3 in the former and $119+23.6$ in the latter ( $p=0.798)$. Mean age of students in the teacher centred school was $28 \pm 5.28$ years, while that of the student-centred school was $23 \pm 1.83$ years $(\mathrm{p}<0.05)$.

Conclusion: The mean total DREEM score proximity between the schools suggests that the younger students using a more student-centred curriculum have less of an appreciation of their improved learning environment than is expected. Thus, the hidden curriculum could be lagging behind the written one. The older students in the teacher centred environment have a more mature appreciation of their learning climate.

Funding: Personal sources

Keywords: medical education, Nigeria, curriculum, DREEM

\section{INTRODUCTION}

Medical education in Sub-Saharan Africa faces numerous challenges and constraints. Policy makers have failed to prioritise health, implement good health policies, invest in basic infrastructural development or address recent security challenges. ${ }^{1}$ Sub-Saharan Africa suffers $27 \%$ of the world's disease burden but constitutes only $12 \%$ of the world's population and has a meagre $1.7 \%$ of the world's physicians. ${ }^{1}$

Low investment in healthcare stifles growth of medical education programmes over time and static education programmes in medical school will result in graduates who are ill equipped to service the needs of the society. ${ }^{2}$ This link between medical curricula and the health of the population was established by the Flexner report over a century ago. ${ }^{2}$
Curriculum may be defined as "a statement of the intended aims and objectives, content, experiences, outcomes and processes of a programme, including a description of the structure and expected methods of learning, teaching, feedback and supervision. The curriculum should set out what knowledge, skills and behaviours the trainee will achieve ${ }^{2,3}$ There are different types of curricula viz. formal (or written), hidden, in-use etc. ${ }^{4}$ Student perceptions can be effective for studying the learning environment and thus the curriculum in-use. ${ }^{4}$ Furthermore, students' perception of the curriculum in use, in a given medical school, has been termed the "climate" of that school and is a broad term which encompasses all that the school operationalizes in its prime goal of producing medical graduates. ${ }^{5}$ 
A curriculum or learning environment can also be described in relation to the learning approach that it uses. ${ }^{6}$ Therefore, a curriculum may be described as "traditional" or teacher-centred curriculum (TCC) or "innovative" otherwise known as a student-centred curriculum (SCC) ${ }^{6}$ Nigeria has 31 fully accredited medical schools, while six others have obtained partial accreditation. ${ }^{7}$ The curriculum in use at many of these medical schools has been studied in part or in full. ${ }^{8}$ The majority of Nigerian medical schools utilize a traditional 'teacher-centred" curriculum (TCC). There are many tools for assessing the learning environment or effective curriculum in a medical school. ${ }^{9,10,11}$

However, the Dundee Ready Education Environment Measure (DREEM) questionnaire is the most widely applied tool for studying the educational aspect of the learning climate. ${ }^{12}$ It has been validated in many countries and over a wide spectrum of health professions students. ${ }^{9,10,11,12}$ It has also been applied in medical schools within Nigeria. ${ }^{13,14,15}$ The DREEM inventory provides the perception of the learning environment by the student, which gives managers of the health professions institutions, objective criteria for making changes that would facilitate learning. ${ }^{16}$

DREEM has also been found to be a predictor of academic performance. ${ }^{16}$ Furthermore, it has been used to compare the learning environment before and after a curricular change at the same medical school. ${ }^{17}$ Critically, the educational climate can be changed in such a way as to improve the quality of medical education; the DREEM inventory provides rungs on which the growing medical school can climb towards achieving their goals and objectives. ${ }^{5,18}$ However, there is no standardised method for reporting the results of the DREEM inventory. ${ }^{19}$ The DREEM inventory and its application in educational environments has been excellently reviewed by Miles and colleagues. ${ }^{19}$

The aim of this study was to report the DREEM status of two Nigerian medical schools operating a traditional "teacher-centred" (TCC) and a more contemporary, "student-centred" (SCC) curriculum, respectively. The TCC School would be assumed to serve as a baseline for the SCC school - highlighting the effectiveness of the curricular change in the latter. In addition, this study compared the results to identify differences in the perceived learning environments between these different curricular approaches, within the Nigerian context. It was hypothesised that the mean total DREEM score of the SCC school would be significantly higher than that of the TCC School.

\section{METHODS}

This study used the DREEM questionnaire as the tool for the assessment of the learning environment in the two institutions. The DREEM questionnaire is composed of 50 questions in five subscales (the minimum and maximum score groupings are shown for each subscale, with their respective interpretation): student's academic perception of self (APS), (8 items: 0-8 Feelings of total failure; 2532 Confident), student's perception of atmosphere (PA), (12 items: 0-12 A terrible environment; 37-48 A good feeling overall), student's social self-perceptions (SSP), (7 items: 0-7 Miserable; 22-28 Very good socially), student's perception of learning (PL), (12 items: 0-12 Very poor; 37-48 Teaching highly thought of) and student's perception of teachers (PT), (11 items: 0-11 Abysmal; 34-44 Model teachers). Each item answer is graded on a scale 0 - strongly disagree to 4 - strongly agree. Reverse coding is used for items $4,8,9,17,25,35,39,48$ and 50. A higher summative score indicates a more efficient learning environment, up to a maximum of 200.

A rubric for interpreting the global score is as follows:

- $0-50 \quad$ Very poor

- 51-100 Plenty of problems

- 101-150 More positive than negative

- 151-200 Excellent

The tool can be analysed at three levels - individual items scores, subscale summary scores and total DREEM scores. Appraising the mean score of the individual items for all participants can identify specific strengths and weaknesses of the educational environment concerned. Subscale assessment is performed by summing up the results of all items in a subscale for each participant and then finding the mean value of the summed scores (subscale summary score).

Score descriptors have been developed to help interpret the scores. For individual items, those with mean scores $\leq 2$ require attention; those $\geq 3.5$ are strong and those between 2 and 3 could be improved. In this study, scores > 3 were considered as high scores and indicated areas in which the index school was doing fairly well. At each medical school, the DREEM inventory was administered as a paper questionnaire to final year medical students, in class, during a 'block posting', in which all student subgroups were combined to attend their core lectures jointly. The data collection was performed on a single day in either school and data collection at both sites occurred no more than one month apart in 2016.

Ethical clearance was obtained via certificate number UI/EC/16/0333. The target population was the entire final year student population in each medical school. 
Informed consent was obtained from each respondent in the form of a signature and date, on a consent form attached to an information leaflet within the questionnaire. Responses were collated and assessed using the scoring rubric designed for the DREEM inventory. The various domains of the DREEM questionnaire were subjected to subgroup analyses. The independent t-test was used to compare the results obtained from the two medical schools.

\section{RESULTS}

There was a total of 138 respondents comprising 67 males and 71 females. There were 50 respondents from the medical school with a traditional curriculum (TCC) and 88 respondents from the school running a studentcentred curriculum (SCC). Response rate at the TCC site was $96.2 \%$ of the total final year student population of 52 students. Response rate at the SCC was $59.1 \%$ of the total student population of 149 final year students.

Table 1 Sample size, mean age, total and subscale DREEM scores for both medical schools in 2016

\begin{tabular}{|c|c|c|c|c|}
\hline Characteristic & SCC & TCC & p-value & Interpretation \\
\hline Sample size & 88 & 50 & & \\
\hline Mean age* & $23 \pm 1.83$ & $28 \pm 5.28$ & $<0.05$ & $\begin{array}{l}\text { Significantly younger } \\
\text { population }\end{array}$ \\
\hline $\begin{array}{l}\text { Mean total } \\
\text { DREEM score }\end{array}$ & $119 \pm 23.6$ & $117+22.34$ & & $\begin{array}{l}\text { More positive than nega- } \\
\text { tive }\end{array}$ \\
\hline Mean PL & $30 \pm 6.39$ & $29 \pm 6.24$ & & More positive \\
\hline Mean PT & $25 \pm 5.67$ & $25 \pm 5.98$ & & Right direction \\
\hline Mean APS & $22 \pm 4.46$ & $22 \pm 3.75$ & & $\begin{array}{l}\text { More on the positive } \\
\text { side }\end{array}$ \\
\hline Mean PA & $28 \pm 6.12$ & $27 \pm 7.17$ & & $\begin{array}{l}\text { More positive atmos- } \\
\text { phere }\end{array}$ \\
\hline Mean SPS & $15 \pm 3.37$ & $14 \pm 3.82$ & & $\begin{array}{l}\text { SCC - Not too bad } \\
\text { TC - Not a nice place }\end{array}$ \\
\hline
\end{tabular}

The DREEM questionnaire was deployed in the TCC institution on $25^{\text {th }}$ August 2016 while it was deployed in the SCC institution on $21^{\text {st }}$ September 2016, less than a month later. Table 1 compared the mean age, total and subscale DREEM scores for both medical schools.

Items in the DREEM score with values less than 2 and greater than 3 are shown in Table 2 and Table 3 respectively.

\section{DISCUSSION}

This study set out to compare DREEM scores between two Nigerian medical schools that administer two different types of medical curricula - one traditional and the other student-centred. It was hypothesised that DREEM scores would be significantly higher in the SCC school, as the learning environment should be more 'learner-oriented' and therefore more effective for learning. ${ }^{20}$
Table 2 Items in the SCC and TCC schools with a mean DREEM score $<2$ in 2016

\begin{tabular}{|c|c|c|}
\hline \multirow[t]{2}{*}{ Item No. } & \multicolumn{2}{|c|}{$\begin{array}{l}\text { Mean DREEM } \\
\text { score }\end{array}$} \\
\hline & SCC & TCC \\
\hline $\begin{array}{l}\text { 3. There is a good support system for } \\
\text { students who get stressed }\end{array}$ & 1.0 & 1.0 \\
\hline 8. The teachers ridicule the students & 1.5 & 1.4 \\
\hline 9. The teachers are authoritarian & 1.5 & 1.6 \\
\hline $\begin{array}{l}\text { 11. The atmosphere is relaxed during the } \\
\text { ward teaching }\end{array}$ & 1.6 & 1.7 \\
\hline 12. This school is well timetabled & $>2$ & 1.5 \\
\hline 13. The teaching is student centered & $>2$ & 1.8 \\
\hline 14. I am rarely bored on this course & 1.7 & 1.5 \\
\hline $\begin{array}{l}\text { 25. The teaching over-emphasises factual } \\
\text { learning }\end{array}$ & 1.8 & 1.7 \\
\hline 27. I am able to memorise all I need & 1.6 & 1.9 \\
\hline $\begin{array}{l}\text { 29. The teachers are good at providing } \\
\text { feedback to students }\end{array}$ & 1.6 & 1.7 \\
\hline $\begin{array}{l}\text { 42. The enjoyment outweighs the stress of studying } \\
\text { medicine }\end{array}$ & 1.4 & 1.1 \\
\hline
\end{tabular}

Table 3 Items in the SCC and TCC schools with a mean DREEM score > 3 in 2016

\begin{tabular}{|c|c|c|}
\hline \multirow[t]{2}{*}{ Item No. } & \multicolumn{2}{|c|}{$\begin{array}{c}\text { Mean } \\
\text { DREEM } \\
\text { score }\end{array}$} \\
\hline & SCC & TCO \\
\hline 1. I am encouraged to participate in class & $<3$ & 3.1 \\
\hline 2. The teachers are knowledgeable & 3.4 & 3.6 \\
\hline 10. I am confident about my passing this year & 3.4 & 3.6 \\
\hline $\begin{array}{l}\text { 45. Much of what I have to learn seems relevant to a career in } \\
\text { medicine }\end{array}$ & 3.1 & 3.2 \\
\hline
\end{tabular}

In addition; the TCC school would serve as a baseline for the DREEM score of a Nigerian medical school prior to change from a teacher centred to a student-centred curriculum.

Our study, however, showed that the total DREEM scores of both medical schools were about the same more positive than negative, and that the difference in the actual scores was not statistically significant (Table 1). In addition, scores on the subscales were similar and any differences observed, were not statistically significant. All the scores were in the third band on the DREEM score chart, except in the SPS subscale, where the scores straddled the second (TCC) and third (SCC) bands. 
The main statistically significant difference between the two schools was that the participants in the TCC were on average, at least 5 years older than those in the SCC $(p<0.001)$. In addition, it was observed that the mean age of the males in both schools was significantly older than that of the females $(\mathrm{p}=0.001)$.

These findings concur with those of two earlier DREEM studies in Nigerian medical schools, in which the scores of 118 and 108 are in the same band as in this study demonstrating a student perception that was generally more positive than negative. ${ }^{13,14}$ Results of a DREEM study from a UK medical school with a student centred curriculum however, are higher than the Nigerian studies but within the same band $-133 .{ }^{21}$ On the contrary, Bassaw et al. reported a mean total DREEM score of 109.9 from a teacher-centred curriculum medical school in Trinidad, which was lower than that (119.23) obtained in the present study. ${ }^{10}$

To our knowledge, this is the first study that set out to compare 'in-country' DREEM scores between medical schools with different curricula, for students in the same year and within a similar period. Including students in the same year and within the same period (less than a month apart) was done in a bid to reduce selection bias. Some possible confounding factors however, include the age differences between the two samples and between the two genders. In addition, the lower response rate of the SCC institution may have had an influence on its average total DREEM score.

However, the lack of a significant difference between the DREEM scores suggests that the students in the two schools have similar perceptions of their learning environments. Thus the student-centred written curriculum is yet to produce significant changes in the educational climate of the SCC school. This suggests the need for an assessment of educational climate as a pivot for evidence-based curricular change, in addition to needs and other assessments of the curriculum. ${ }^{22}$ The DREEM tool has come under scrutiny with respect to its psychometric properties. $^{23}$

The Manchester Clinical Placement Index (MCPI) appears to compare favourably with the DREEM but MCPI is not culturally diverse and may not be relevant in the Nigerian medical education structure at present. ${ }^{24}$

The borderline score for social perceptions of self (SPS) $-15 \pm 3.37$ merits attention (Table 1). The items with scores $<2$ in this subscale were item 3 (There is a good support system for students who get stressed) - mean score of 1.0 and item 14 (I am rarely bored on this course) - mean score of 1.7. This data provides specific areas for the medical school managers to resolve student difficulties i.e. to provide a good support system for students who are stressed and to make the curriculum in-use more interesting. It has been noted that stress in medical students is associated with poorer academic performance and that formal mechanisms for coping with stress are necessary. ${ }^{25,26}$

This subscale is also of concern to the managers of the TCC school as the mean DREEM score, though borderline, was in the 'not a nice place' band. It is of interest that the items with mean scores $<2$ in the SPS subscale were the same as for the SCC i.e. items 3 and 14 (Table 2). Some other DREEM studies in Nigeria have shown the mean score for item three to be 0.66 and $1.39 .^{14,15}$ This suggests that formal mechanisms for dealing with stress may be lacking in Nigerian medical schools and this critical infrastructural gap merits further study and remediation.

The concurrence of most of the items in tables 2 and 3 between the two schools is especially noted. These twin results reinforce the observation of similar perceptions of the learning environment, by students in both schools. This is a concern for managers especially at the institution with the more contemporary SCC, which incidentally is an older and established medical school with a good track record. This may be disconcerting because it suggests that despite the change in the written curriculum, the hidden curriculum may be undergoing a much slower evolution, thus masking the gains of the modernised curriculum design.

Regular studies of the learning environment for students and teachers would help monitor the pace of curricular change and its impact on stakeholders. Such studies indicate the shift from a learning institution into a learning organism. ${ }^{5}$ In an earlier Nigerian DREEM study, age was noted to have an influence on the perception of the students but this was not further analyzed. ${ }^{14}$ Kick et al noted that older medical students were more caustic in their comments about the learning experience. ${ }^{27}$ Some other items in table 2 indicate the inadequate climate with respect to teachers - items 8, 9, 11, 25 and 29. These are areas that should be fairly adequate in a student centred curriculum - the low scores bring up a concern that the approach to students may not be student centred. ${ }^{28}$

This is in keeping with the borderline score of 2.1 for item 13 (The teaching is student centred) in the SCC school. Only two-thirds of the students in the SCC school responded to the questionnaire. It has been noted that for students who know a school well (final year students in this study), the climate could be consensual. ${ }^{27}$ 
However, there could have been less of a response bias, if a larger percentage of students in the SCC had participated, expressing either positive or negative perceptions respectively.

Furthermore, the instrument was administered at one sitting, which could subject the findings to the frame of mind of the students at the time. Although, most articles on the DREEM questionnaire have also used this method. Lastly, the DREEM and other learning environment tools view the complex issue of the learning environment only from one perspective - the student, who is intuitively at the receiving end of the operationalized curriculum. The perspectives of the faculty, who implement the curriculum in the learning environment is also an important factor to be considered. The perspectives of teachers and postgraduate students have also been studied. ${ }^{29}$

The findings from this study provide more avenues for further research than definite answers. There is a suggestion that the older students in the TCC are more tolerant of the less student-centred program and more appreciative of its benefits, while the younger students at the SCC are less so. This makes a case for more study about the mechanisms of student perception of their learning environment, especially with respect to age. It brings up the hidden curriculum to which the students in the SCC may be responding, which could be at variance with the written curriculum. ${ }^{4}$

Thus, the policy makers need to consider harmonising both the written and hidden curriculum, as well as 'selling' the more modern curriculum to the younger students. Provision of student counselling and remediation of stressful factors in the learning environment is needed at both schools. It is also possible that the Nigerian medical environment, which is still mostly traditional, does have some strength, which should be retained even as more efficient curricula are introduced. Transferability of these findings is relevant with respect to the importance of serial studies of the learning environment. Further research with larger samples is required to investigate these issues.

The mean total DREEM score proximity between the medical schools suggests that the younger students using the more student-centred curriculum have less of an appreciation of their learning environment than is expected. It is possible that there are unnoticed constraints within the hidden curriculum. Thus, the hidden curriculum could be lagging behind the written one. It is also possible that this may be a result of the higher, more idealistic, expectations of the younger generation of students at the SCC medical school. Conversely, the older students in the teacher centred environment have a more mature appreciation of the learning climate.
Provision of student counselling, improvement of existing feedback mechanisms and prompt remediation of stressful factors in the learning environment is needed at both schools.

\section{CONCLUSION}

This study emphasizes the usefulness of an assessment of the learning environment as a pivotal component of curricular change and suggests that the mean age of a student population may have an impact on their perception of the learning environment.

\section{ACKNOWLEDGEMENT}

The authors appreciate the final year students at the time of this study in both medical schools as the key participants in this work.

\section{REFERENCES}

1. Chen C, Buch E, Wassermann T, Frehywot S, Mullan F, Omaswa F, et al. A survey of Sub-Saharan African medical schools. Hum Resourc Health 2012;10:4. doi: 10.1186/1478-4491-10-4

2. Frenk J, Chen L, Bhutta ZA, Cohen J, Crisp N, Evans $\mathrm{T}$, et al. Health professionals for a new century: transforming education to strengthen health systems in an interdependent world. Lancet 2010;376:192358. doi: 10.1016/S0140-6736(10)61854-5

3. GMC. Standards for curricular and assessment Systems. 2010 (gmc-uk.org). Retrieved October 2016 from http://www.gmc-uk.org/education/postgraduate/26728.asp.

4. Lempp H, Seale C. The hidden curriculum in undergraduate medical education: qualitative study of medical students' perceptions of teaching. BMJ 2004;329(7469):770-73.

doi.org/10.1136/bmj.329.7469.770

5. Genn JM. AMEE Medical Education Guide No. 23 (Part 1): Curriculum, environment, climate, quality and change in medical education - a unifying perspective. Med Teach 2001;23:337-44. doi.org/10.1080/01421590120063330

6. Newble DI, Clarke RM. The approaches to learning of students in a traditional and in an innovative problem-based medical school. Med Educ 1986;20:26773.

7. MDCN. Accredited Medical Schools. 2016 (mdcn.gov.ng). Retrieved October 14, 2016 from https://www.mdcn.gov.ng/page/accredited-medicalschools.

8. Ibrahim M. Medical education in Nigeria. Med Teach 2007;29:901-5. doi.org/10.1080/01421590701832130 
9. Al-Hazimi A, Al-Hyiani A, Roff S. Perceptions of the educational environment of the medical school in King Abdul Aziz University, Saudi Arabia. Med Teach 2004;26:570-73. doi.org/10.1080/01421590410001711625

10. Bassaw B, Roff S, McAleer S, Roopnarinesingh S, De Lisle J, Teelucksingh S, et al. Students' perspectives on the educational environment, Faculty of Medical Sciences, Trinidad. Med Teach 2003;25:522-26. doi.org/10.1080/0142159031000137409

11. Avalos G, Freeman C, Dunne F. Determining the quality of the medical educational environment at an Irish medical school using the DREEM inventory. Ir Med J 2007;100:522-25.

12. Roff S, McAleer S, Harden RM, Al-Qahtani M, Ahmed AU, Deza H, et al. Development and validation of the Dundee Ready Education Environment Measure (DREEM). Med Teach 1997;19:295-99.

13. Buhari MA, Nwannadi IA, Oghagbon EK, Bello JM. Students' perceptions of their learning environment at the College of Medicine, University of Ilorin, Southwest, Nigeria. W Afr J Med 2014;33:141- 45.

14. Roff S, McAleer S, Ifere OS, Bhattacharya S. A global diagnostic tool for measuring educational environment: comparing Nigeria and Nepal. Med Teach 2001;23:378-82. doi.org/10.1080/01421590120043080

15. Odole AC, Oyewole OO, Ogunmola OT. Nigerian Physiotherapy Clinical Students' Perception of their Learning Environment Measured by the Dundee Ready Education Environment Measure Inventory. Int J High Educ 2014;3:83-91. doi.org/10.5430/ijhe.v3n2p83

16. Mayya S, Roff S. Students' perceptions of educational environment: a comparison of academic achievers and under-achievers at kasturba medical college, India. Educ Health (Abingdon) 2004;17:280-91. doi.org/10.1080/13576280400002445

17. Finn Y, Avalos G, Dunne F. Positive changes in the medical educational environment following introduction of a new systems-based curriculum: DREEM or reality? Curricular change and the Environment. Ir J Med Sc 2014;183:253-8. doi.org/10.1007/s11845-013-1000-4

18. Roff S, McAleer S. What is educational climate? Med Teach 2001;23:333-34. doi.org/10.1080/01421590120063312

19. Miles S, Swift L, Leinster SJ. The Dundee Ready Education Environment Measure (DREEM): a review of its adoption and use. Med Teach 2012;34:e620-34.

doi.org/10.3109/0142159X.2012.668625
20. Kiguli-Malwadde E, Olapade-Olaopa EO, Kiguli S, Chen C, Sewankambo NK, Ogunniyi AO, et al. Competency-based medical education in two SubSaharan African medical schools. Adv Med Educ Pract 2014;5:483-89. doi.org/10.2147/AMEP.S68480

21. Cocksedge ST, Taylor DC. The National Student Survey: is it just a bad DREEM? Med Teach 2013;35:e1638-43. doi.org/10.3109/0142159X.2013.835388

22. Olopade FE, Adaramoye OA, Raji Y, Fasola AO, Olapade-Olaopa EO. Developing a competencybased medical education curriculum for the core basic medical sciences in an African Medical School. Adv Med Educ Pract 2016;7:389-98. doi.org/10.2147/AMEP.S100660

23. Dornan T, Muijtjens A, Graham J, Scherpbier A, Boshuizen H. Manchester Clinical Placement Index (MCPI). Conditions for medical students' learning in hospital and community placements. Adv Health Sci Educ Theory Pract. 2012;17:703-16. doi.org/10.1007/s10459-011-9344-x

24. Kelly M, Bennett D, Muijtjens A, O'Flynn S, Dornan T. Can less be more? Comparison of an 8-item placement quality measure with the 50-item Dundee Ready Educational Environment Measure (DREEM). Adv Health Sci Educ Theory Pract. 2015;20:1027-32. doi.org/10.1007/s10459-015-9582-4

25. Wilkinson TJ, McKenzie JM, Ali AN, Rudland J, Carter FA, Bell CJ. Identifying medical students at risk of underperformance from significant stressors. BMC Med Educ 2016;16:43-016-0565-9. doi:10.1186/s12909-016-0565-9

26. Saeed AA, Bahnassy AA, Al-Hamdan NA, Almudhaibery FS, Alyahya AZ. Perceived stress and associated factors among medical students. J Fam Comm Med 2016;23:166-71. doi.org/10.4103/2230-8229.189132

27. Kick S, Adams L, O'Brien-Gonzales A. Unique issues of older medical students. Teach Learn Med 2000;12:150-55.

28. Nottidge TE, Louw AJN. Self-directed learning: Status of final-year students and perceptions of selected faculty leadership in a Nigerian medical school - a mixed analysis study. Afr $J$ Health Prof Edu 2017;9:29-33. doi.org/10.7196/AJHPE.2017.v9i1.708

29. Roff S, McAleer S, Skinner A. Development and validation of an instrument to measure the postgraduate clinical learning and teaching educational environment for hospital-based junior doctors in the UK. Med Teach 2005;27:326-31. doi.org/10.1080/01421590500150874 